\title{
Hybrid Entrepreneurship: How and Why Entrepreneurs Combine Employment with Self-Employment
}

\author{
Marina Z. Solesvik
}

\author{
" I never had it in mind that I would start $a$ ") \\ company one day and it would really be \\ successful. I have just been motivated by \\ working on interesting technology.
}

\author{
Pierre Omidyar \\ Entrepreneur who founded eBay \\ while in full-time employment
}

\begin{abstract}
Changes in the labour market and growth in the diversity of non-standard working arrangements have heightened the interest of policy makers and entrepreneurship researchers in "hybrid entrepreneurship", which is a combination of employment and entrepreneurship. This form of entrepreneurship is particularly popular among highly educated professionals in the high-technology and R\&D sectors. With the goal of improving our understanding and defining a research agenda for this phenomenon, I examined the relevant literature to clarify definitions and I undertook a research study to examine first-hand, through a longitudinal case study, the experiences of two hybrid entrepreneurs, one who intended to become a full-time entrepreneur and one who wish to be hybrid entrepreneur. The key result of the study emphasizes that hybrid entrepreneurs should not be considered as a homogeneous group: some hybrid entrepreneurs may always stay at their waged jobs and others may tend to become full-time entrepreneurs. The results have implications for policy makers wishing to encourage hybrid entrepreneurship and for researchers wishing to undertake further research into this phenomenon.
\end{abstract}

\section{Introduction}

The constantly falling rates of self-employment in developed countries concern policy makers. Individuals are steadily more reluctant to take risks and start their own firms if they have secure jobs with high salaries and good social benefits (Schmitt \& Lane, 2009). Previous research demonstrates that there is a significant part of the population in different countries who have an entrepreneurial spirit and wish to start an own business one day (Kelly et al., 2016). The share of latent entrepreneurs - those individuals who are otherwise employed but wish to start their own business - is estimated from $27 \%$ in Norway to $80 \%$ in Poland (Blanchflower et al., 2001). In $2012,37 \%$ per cent of Europeans and $46 \%$ of US citizens wished to be their own bosses (European Commission, 2013). In emerging economies, the share of people willing to be self-employed is even higher: $56 \%$ in China and $82 \%$ in Turkey (European Commission, 2013).
For many people, dropping their waged work and starting their own firm is a difficult decision. However, by undertaking both types of work simultaneously, hybrid entrepreneurship could provide an attractive bridge from employment to self-employment. Though the notion of part-time or hybrid entrepreneurship is not new (Smallbone \& Welter, 2001), only recently have hybrid entrepreneurs started to attract the attention of policy makers and scholars (Folta et al., 2010; Petrova, 2005; Schulz et al., 2016). This growing interest of scholars and policy makers can be explained by recent changes in the employment market, where there has been a dramatic shift towards temporary or part-time jobs (Kalleberg, 1999).

Relative to full-time entrepreneurs, hybrid entrepreneurs show higher levels of education (Folta et al., 2010) and human capital (Petrova, 2012). Thus, the role of hybrid entrepreneurship is expected to be greater in 


\section{Hybrid Entrepreneurship: How and Why Entrepreneurs Combine Employment with Self-Employment} Marina Z. Solesvik

knowledge-intensive and innovative industries. The share of hybrid entrepreneurs in R\&D high-technology startups is estimated to be $42 \%$ in Germany (Bretz et al., 2015) and 58\% in Sweden (Folta et al., 2010). Moreover, high-technology industries have yielded some wellknown examples of billion-dollar businesses that were created by their founders while they were employed elsewhere. For example, Steve Wozniak founded Apple while he was an engineer at Hewlett-Packard, and while Pierre Omidyar was working for a software development firm, he launched the firm that would eventually become eBay (Livingston, 2007).

But, do all hybrid entrepreneurs intend to become fulltime entrepreneurs? In describing a pathway to fulltime entrepreneurship, Thorgen and colleagues (2016) distinguished between first-step and second-step entrepreneurial decisions. The first-step entrepreneurial decision is made when a person chooses to become a hybrid entrepreneur. The second-step decision is associated with the switching from hybrid to full-time selfemployment. However, their study of hybrid entrepreneurs in Sweden also highlighted that not all hybrid entrepreneurs intend to become full-time entrepreneurs (Thorgen et al., 2016). Similarly, Schulz, Urbig, and Procher (2016) concluded that hybrid entrepreneurs are not a homogeneous group. They found that more highly educated hybrid entrepreneurs act differently than their less educated counterparts, and they call for more research exploring different types of hybrid entrepreneurship. So far, research into hybrid entrepreneurship has mainly been quantitative (Burke et al., 2008; Folta et al., 2010; Petrova, 2012; Raffiee \& Feng, 2014; Schulz et al., 2016; Thorgen et al., 2016) and, therefore, our understanding of the motives, behaviours, and intentions of hybrid entrepreneurs is limited.

This article describes a study that is both qualitative and longitudinal, which can hopefully shed light on these important aspects of hybrid entrepreneurship. In addition to deeply exploring the motives, behaviours, and intentions of different types of hybrid entrepreneurs, I also aim to clarify the definition of the terms "hybrid entrepreneur" and "hybrid entrepreneurship" to better distinguish these terms from related concepts.

A qualitative study is appropriate when a researcher wants to gain deep insight into a phenomenon. Furthermore, qualitative studies are suitable when asking "How?" and "Why?" research questions. The two research questions that guided this study are:

\section{Why do individuals select a hybrid career path?}

\section{Why do some individuals prefer to remain hybrid en- trepreneurs and why do others aim to become full- time entrepreneurs?}

In this article, I first introduce and analyze existing definitions of hybrid entrepreneurship and review the current state of research on the topic. Next, I present and analyze two longitudinal cases of hybrid entrepreneurs observed from 2006 to 2015. Finally, I offer conclusions and present a future research agenda.

\section{Theoretical Background}

\section{Definitions}

The relevant literature reveals some inconsistency in the definitions related to hybrid entrepreneurship (Table 1). On one hand, some scholars define hybrid entrepreneurs as "individuals who mix their time in both self-employment and wage work" (e.g., Folta et al., 2010), while others would call these same individuals "part-time entrepreneurs" (e.g., Petrova, 2012). In contrast, Schulz, Urbig, and Procher (2016) use the term "part-time entrepreneur" without implying that these individuals have other paid employment, and they use "hybrid entrepreneurship" to refer specifically to a combination of paid employment and self-employment. On the other hand, some scholars refer to hybrid entrepreneurs quite differently, as individuals who start firms combining non-profit and for-profit activities (Battilana et al., 2012; Dees, 1998; Fowler, 2000; Nicholls, 2008). This last usage is quite different and is beyond the scope of the current discussion. In this article, I am specifically interested in individuals who combine entrepreneurial activities with wage work, which is in line with the definition proposed by Folta and colleagues (2010).

\section{State of research on hybrid entrepreneurship}

In countries with strong social security systems, high salaries, and other benefits for employees (i.e., a short working day, generous social security and health insurance plans available from employers, long and paid maternity and paternity leave), some individuals may be reluctant to become self-employed. For example, only $27 \%$ of Norwegians report wanting to be self-employed (European Commission, 2013). And this indicator has not changed since 1997, when Blanchflower and associates (2001) carried out their study of self-employment preferences. A similar situation has been observed in other countries with high wages and social security, such as Lichtenstein, Switzerland, Denmark, and Finland (OECD, 2016). So, we know that about a quarter of the population in such countries is attracted 


\section{Hybrid Entrepreneurship: How and Why Entrepreneurs Combine Employment with Self-Employment} Marina Z. Solesvik

Table 1. Summary of existing research on hybrid entrepreneurship

\begin{tabular}{|c|c|c|c|}
\hline Authors & Aim of Study & Method and Sample & Key Findings \\
\hline $\begin{array}{l}\text { Petrova } \\
(2005,2012)\end{array}$ & $\begin{array}{l}\text { To explore the reasons } \\
\text { why some people choose } \\
\text { to be part-time } \\
\text { entrepreneurs. }\end{array}$ & $\begin{array}{l}\text { Quantitative. } 721 \\
\text { nascent entrepreneurs } \\
\text { in the US. }\end{array}$ & $\begin{array}{l}\text { - Part-time entrepreneurs are not limited by financial limitations. } \\
\text { - Risk-averse individuals are more likely to become hybrid entrepreneurs. } \\
\text { • Human capital is very important for hybrid entrepreneurs. }\end{array}$ \\
\hline $\begin{array}{l}\text { Burke et al. } \\
\text { (2008) }\end{array}$ & $\begin{array}{l}\text { To "move beyond } \\
\text { dichotomous depiction of } \\
\text { entrepreneurship and } \\
\text { wage work and begin to } \\
\text { explore the implications } \\
\text { of entrepreneurial } \\
\text { persistence". }\end{array}$ & $\begin{array}{l}\text { Quantitative. 11,361 } \\
\text { individuals from } \\
\text { National Child } \\
\text { Development Study. } \\
\text { Probit analysis. }\end{array}$ & $\begin{array}{l}\text { - They distinguish between "die-hard" and part-time entrepreneurs. } \\
\text { - Having children does not influence selection of hybrid or full-time } \\
\text { entrepreneurship among males. However, it negatively influences female } \\
\text { entrepreneurship. } \\
\text { - Motivation to "be one's own boss" drives females to hybrid } \\
\text { entrepreneurship but not full-time entrepreneurship. For males, this } \\
\text { motive drives them to full-time entrepreneurship. }\end{array}$ \\
\hline
\end{tabular}

$\begin{array}{ll}\text { Folta et al. } & \text { To explore why } \\ \text { (2010) } & \text { individuals prefer a } \\ & \text { hybrid entry to } \\ & \text { entrepreneurship } \\ & \text { compared to full-time } \\ & \text { entrepreneurship and } \\ & \text { whether hybrid } \\ & \text { entrepreneurs are more } \\ & \text { likely to become full-time } \\ \text { entrepreneurs than waged } & \\ & \text { workers. }\end{array}$

Burmeister- To explore the time Lamp et al. allocation between a (2012) waged job and a new entrepreneurial firm.
Quantitative.329,624 observations of 45,000 male waged workers, self-employed and hybrid entrepreneurs in Sweden. Multivariate analysis.
- High-wage earners are more likely to become hybrid entrepreneurs.

- Individuals with high switching costs are also more likely to become hybrid entrepreneurs.

- Hybrid entrepreneurs are more likely to become full-time entrepreneurs than waged workers.
Quantitative.25 nascent • More risk-averse hybrid entrepreneurs allocate fewer hours to a new firm entrepreneurs and 29 undergraduate students. Computerbased experiment. than less risk-averse individuals.

\section{Thorgen et To explore motives of} al. (2014) hybrid entrepreneurs with
a focus on passion as a driving force of entrepreneurship.
Quantitative.262

Swedish hybrid entrepreneurs. Logistic regression analysis.
- Passion is the main motive for hybrid entrepreneurs.

- Older individuals report more passion towards their hybrid businesses.

- Those who work longer hours in their side business report less passion as the main motive.
Raffiee \& To explore whether risk-

Feng (2014) averse and less confident individuals are more likely to become hybrid entrepreneurs than fulltime entrepreneurs.
Quantitative. Analysis of National Longitudinal Survey of Youth, 1979 cohort in the US. Continuous survival analysis.
- Individuals who are risk-averse and report low core self-evaluation are more likely to enter hybrid entrepreneurship compared to full-time selfemployment.

- Hybrid entrepreneurs who successively move into full-time selfemployment have much higher survival rates relative to individuals who enter full-time self-employment straight from a waged job.
Schulz et al. To explore responses of (2016) full-time versus hybrid entrepreneurs to institutional changes.
Quantitative.212,523 individuals in Mexico. Multinomial logit analysis.
- Researchers distinguish between part-time, full-time, and hybrid entrepreneurs.

- Part-time entrepreneurs were less educated than hybrid entrepreneurs in the sample of Mexican entrepreneurs.

- More highly educated hybrid entrepreneurs use ventures to test ideas and explore business opportunities, and they respond quicker to institutional changes than less educated hybrid entrepreneurs and full-time entrepreneurs.
Thorgen et To examine how age al. (2016) relates to the transition from hybrid to full-time entrepreneur.
Quantitative. 256 hybrid entrepreneurs in Sweden. Logistic regression analysis.
- Younger and older hybrid entrepreneurs are more likely to become fulltime entrepreneurs than those in between. 


\section{Hybrid Entrepreneurship: How and Why Entrepreneurs Combine Employment with Self-Employment} Marina Z. Solesvik

to self-employment; however, the actual proportion of a population that is self-employed varies between $10-15 \%$ in different countries (Blanchflower et al., 2001). In other words, there is a substantial gap between those who only have intentions to be self-employed and the actual number of self-employed. And within this gap lies potential for some forms of hybrid entrepreneurship. Indeed, some people may be forced into hybrid entrepreneurship, for example, individuals who are experiencing difficulty obtaining full-time and permanent employment but use self-employment to supplement their earnings. Others may use hybrid entrepreneurship to explore opportunities without given up their main source of income.

There are different reasons why some individuals never realize their entrepreneurial intentions. First, because of a risk of losing monetary and nonmonetary benefits from wage jobs, individuals are not eager to bear opportunity costs. Thus, hybrid entrepreneurship can be an option to earn supplementary income in addition to the income from conventional jobs or to try a new business idea (Schulz et al., 2016). In case of business success and sufficient income from entrepreneurial activity, individuals can switch from hybrid entrepreneurship to full-time self-employment. Second, some people lack resources that can be used as start-up capital. Salary from employment can support novice entrepreneurs and help to overcome the liabilities of newness and smallness. Hybrid entrepreneurs are more likely to operate their businesses using the resources in hand, thereby acting as bricoleurs (Baker \& Nelson, 2005) or effectuators (Sarasvathy, 2001) rather than fulltime entrepreneurs. Apparently, hybrid entrepreneurs may be motivated by a drive to "be their own boss" but can also work under the management of other people if necessary. However, so far, hybrid entrepreneurship has not been investigated from the theoretical perspectives of bricolage or effectuation. Effectuators are good network players (Sarasvathy, 2001), and hybrid entrepreneurs use their time to build their networks while they combine waged and entrepreneurial activities. A key question is how this approach affects the likelihood of entrepreneurial success. So far, there is at least some evidence that the survival rate of firms started by hybrid entrepreneurs is higher than that of firms started by full-time entrepreneurs (Raffiee \& Feng, 2014).

In some contexts, individuals have greater opportunities to become hybrid entrepreneurs. For example, in some countries such as the countries of the former Soviet Union and China, people were forced to be wage workers by law. Entrepreneurship was legally prohib- ited in these countries; all people (with the exception of females with three or more children) were required to be employed by state-owned or collective enterprises (Parsyak \& Zhuravlyova, 2001; Peng, 2001). Able individuals who did not work or study could be found guilty of "parasitism" (Porket, 1989). In such situations, some entrepreneurially oriented individuals participated in the grey economy in addition to earning wages - and acquired quite important skills in combining both types of work (Peng, 2001). Another factor that influences opportunities for hybrid entrepreneurship is an individual's wage in part-time employment. If they cannot earn enough money to support themselves on a part-time wage in the early stages of entrepreneurship, they may be reluctant to "take the leap". Indeed, people occupied in certain well-paying industries, such as academia, medicine, and policing, are well-represented among hybrid entrepreneurs (Folta et al., 2010). From the monetary point of view, the reason for such trend is the difficulty for individuals with fixed wages to increase their working hours and income from their main jobs (Folta et al., 2010).

Thorgren and colleagues (2016) have shown that younger and older adults are more likely to become fulltime entrepreneurs than those in between. The former are less risk-averse because they have not accumulated significant material resources (i.e., they have less to lose) and their opportunity costs (i.e., the wages that they might earn as employees) are not high. As people become older, the probability of becoming self-employed increases (Blanchflower et al., 2001). This phenomenon can be explained by several factors. On one hand, people obtain human and social capital through employment (Burke et al., 2008), both of which contribute to successful entrepreneurship (Solesvik, 2016). On the other hand, older individuals may have accumulated savings and are more likely to have paid back their mortgages. In addition, with their children fully grown, they may have more free time and can take risks in trying a self-employment career path. Notably, the salary level of individuals entering hybrid entrepreneurship is higher than wages of individuals who become full-time entrepreneurs (Raffiee \& Feng, 2014).

Thus, generally speaking, hybrid entrepreneurship is a good way to realize entrepreneurial intentions for riskaverse individuals. Females are more risk-averse compared to their male counterparts (Solesvik et al., 2013). Thus, trying to become a hybrid entrepreneur may be an especially attractive approach for females (Westhead \& Solesvik, 2016), but this topic is underresearched at present. In their comprehensive study of 


\section{Hybrid Entrepreneurship: How and Why Entrepreneurs Combine Employment with Self-Employment} Marina Z. Solesvik

hybrid entrepreneurs, Folta and colleagues (2010) omitted females from their long-term study of hybrid and full-time entrepreneurs.

Another aspect of hybrid entrepreneurship that will require further study is the employer's perspective, which is only briefly mentioned in the literature (Folta et al., 2010). Some employers are very strict and do not allow employees to engage into competing businesses. According to prior research, such restrictions are barriers to entrepreneurship (Stuart \& Sorenson, 2003). However, some employers encourage the entrepreneurial spirit of employees and support them to develop innovative products (Chesbrough, 2002). Successful innovative ideas and developments might give birth to successful spin-offs where employers and inventors might have stakes. This avenue is a promising avenue of research given that hybrid entrepreneurship is likely to become more important in the future.

Based on gaps identified in the literature on hybrid entrepreneurship, I wished to understand why individuals selected a hybrid entrepreneurship career path. I also wanted further our understanding of why some individuals prefer to remain hybrid entrepreneurs while others go on to become full-time entrepreneurs.

\section{Research Method}

As a qualitative approach, I chose a long-term comparative case study method to answer the research questions. I selected two hybrid entrepreneurs who had different levels of human capital, were of different ages, who operated in different industries, and who had different growth motivations. The two case entrepreneurs were also different in their full-time entrepreneurial intentions: the first one wished to keep his hybrid status, and the second one intended to operate his own company on full-time basis. I selected these two cases to contrast them to one other and show the difference between two types of hybrid entrepreneurs.

I interviewed the two hybrid entrepreneurs six times each in the period between 2006 and 2015 so that I could follow the development of their businesses. All interviews were face-to-face and semi-structured, and they were transcribed the day afterwards. I asked some general demographic questions, questions related to current and previous "day jobs" of the entrepreneurs, and questions related to the firms they created through hybrid entrepreneurship. To ensure the confidentiality of the informants, their names have been changed.
In addition to the interview data, I collected secondary information about the informants' companies from the Internet, newspapers, and accounting reports. I also visited their offices in Norway and Germany and observed how they work. I selected entrepreneurs from these two countries because they are among the countries with the lowest rates of self-employment in the world and the level of self-employment is decreasing (World Atlas, 2016). In these countries, increasing support to hybrid entrepreneurs might be a solution for policy makers to increase the level of self-employment.

I analyzed the data following three principles: constant comparison, analytic induction, and theoretical sensibility (Boeije, 2010). I coded the information received from the interviews and secondary sources. The unit of analysis was an entrepreneur. First, I made a withincase analysis of each case. Then, I compared two cases and made a cross-case analysis. I analyzed the data with the help of existing theories and research on hybrid entrepreneurship.

\section{Case 1: The Inventor}

Mr. Müller is a hybrid entrepreneur. He combines his single business with his academic work as the chair of a university computer science department. Mr. Müller used to work as the R\&D director for a branch of a world-leading ICT company in Europe. One of his inventions brought millions of dollars in revenue to his employer. However, Mr. Müller only received a modest bonus of DM3000 for his invention. He decided to quit the ICT company and became a university professor. Mr. Müller felt that he had reached his peak at the ICT company and that further promotion would be difficult. On the side, he had been working on an invention that scared away birds from eating crops in gardens and fields. One day, his neighbour suggested that he should start selling his invention. The neighbour helped Mr. Müller to promote the product by sending letters to potential customers, both businesses and private individuals. The sales of the product went well, and Mr. Müller started to sell the product around the world. His initial manufacturing efforts were modest: he even taught his children and other family members how to assemble the devices. But, Mr. Müller later invented a more professional version of the device that was used by airports around the world to keep birds away from planes. As of the latest interview, the business is doing well. Mr. Müller is close to retirement now, but he does not want to quit his secure employment as a university professor. Furthermore, he never 


\section{Hybrid Entrepreneurship: How and Why Entrepreneurs Combine Employment with Self-Employment} Marina Z. Solesvik

did intend to become a full-time entrepreneur when he started this journey back in 2006. The income from his business gives Mr. Müller (and his family) additional income that supplements his income from his full-time job. He has accumulated significant personal savings, and he owns two houses and a collection of luxury cars. Interestingly, Mr. Müller is careful not to reveal the extent of his wealth to his employer. For example, despite owning several luxury cars, he uses a tiny, cheap car to drive to the university. He was also concerned about needing to disclose financial information related to his revenue and assets to the university. He plans to transfer his assets to a trust if the university decides he must disclose this information.

\section{Case 2: The Shift Worker}

Mr. Jensen lived in a rural area of Western Norway and worked as a sailor and electrician on a fishing vessel. He would work four weeks at sea per shift, then he would stay for four weeks at home. Building on his experience and professional education in electrical services, Mr. Jensen started a private electrical company in his 30s. When not at sea, he installed air conditioning and heat pumps in households in the countryside where he lived. Although Mr. Jensen initially did the electrical work alone, he eventually employed his cousin to perform the installations when he was at sea. The company gradually grew, and Mr. Jensen built premises for the business next to his home. Mr. Jensen had been operating as a hybrid entrepreneur but then applied for one-year leave of absence from his duties on the fishing vessel in order to become a full-time entrepreneur. Mr. Jensen's employer did not grant him leave of absence. There was no conflict of interest, give that Mr. Jensen's duties on board were different than the services provided through his private business. But, for the employer, it likely would have been difficult to find a reliable and experienced person who will agree to work only for one year on the fishing vessel. Mr. Jensen then quit his fishing vessel employment position and became a full-time entrepreneur. However, the income from his private electrical company was not sufficient. He decided to go back to paid employment as a sailor for another shipping company but he continued to run his own private electrical company. Mr. Jensen acquired a license to install complete electrical solutions in new houses. This opened a new market and brought many new customers. When the income from the electrical company was stable and secure, Mr. Jensen stopped working as a sailor and became fully self-employed and self-sufficient. He expanded his private electrical company and started a shop in a countryside selling electrical appliances for households and firms. In 2014, Mr. Jensen's private electrical company was one of six gazelle firms in the county. Mr. Jensen recently bought a new office for his firm, which now employs six electricians. His family members (a wife and a daughter) also work in his business by assisting in the shop. Mr. Jensen now derives wealth from income from several businesses, including the electrical services company, the electrical appliances shop, and a property management shop.

\section{Analysis and Discussion}

These two case entrepreneurs have some similarities and differences. In each cases, the entrepreneur was male. They each had a well-paying "day job" before they added entrepreneurship. The social security benefits were quite good in both cases. Importantly, in both cases, the hybrid entrepreneurs also had enough spare time in their "day jobs" to devote to their businesses. Also, they each could use income generated from their employment as start-up capital for their firms. However, investments into the new ventures were moderate. In Case 1 (Mr. Müller, the inventor), investments covered the cost of postage and supplies to inform customers by direct mail about the invention and the cost of ordering electronic components for the bird-scaring devices. In the Case 2 (Mr. Jensen, the shift worker), the entrepreneur acquired a used pickup truck and some instruments for the electrical installations. Neither entrepreneur had previous experience in business ownership. Both businesses made quite good progress and were profitable for their owners, but neither was particularly growth-oriented.

The differences between the cases were also notable. The entrepreneur in Case 1 is older. He started his business in his late $40 \mathrm{~s}$. He had a PhD degree before he switched from his industrial career to his academic career. The entrepreneur in Case 2 was younger, but still not very young, when he started his business. He was about 30 years old when the Norwegian government launched a subsidy programme to households that equipped their houses with heat pumps. The entrepreneur in Case 2 saw an opportunity to earn some extra money during the four weeks when he was at home between shifts at sea. His shift work as a sailor and his high salary provided him time and resources to starting a business alongside his main occupation. He had no higher education but had accumulated specific human capital through 10 years of employment as an electrician. He is quite sociable with many friends who were his first customers. The entrepreneurs were also 


\section{Hybrid Entrepreneurship: How and Why Entrepreneurs Combine Employment with Self-Employment} Marina Z. Solesvik

different in terms of their social statuses and work conditions. In Case 1, the entrepreneur had a high social status as professor and the leader of an institute at the university, where he enjoyed comfortable working conditions. In Case 2, the entrepreneur's “day job" was performed in quite a harsh and dangerous environment in the North Sea and other polar waters. In Case 1, the entrepreneur did not have intentions to be a full-time entrepreneur. In Case 2, the entrepreneur had a clear goal to become a full-time entrepreneur and to quit his waged job. He succeeded on his second attempt. Notably, if he had decided from the beginning to drop his full-time job and become a full-time entrepreneur right away instead of first becoming a hybrid entrepreneur, he probably would have failed. It took him about 10 years to build his business and gain enough customers to secure sustainable revenue for the business and family.

\section{Conclusion}

The two cases examined here show that hybrid entrepreneurship is a viable path for people willing to realize their entrepreneurial ambitions in a lower-risk and organic way. In line with prior research (Folta et al., 2010), the hybrid entrepreneurs in this study have enough free time to do business alongside their "day jobs". Previous research argues that hybrid entrepreneurs are more riskaverse than individuals switching straight from waged jobs to full self-employment (Folta et al., 2010). The case evidence here suggests that the two entrepreneurs are not more risk-averse than full-time entrepreneurs but may be more realistic and know the pros and cons of entrepreneurship. Pursuing the hybrid entrepreneurship path allows entrepreneurs to test their business ideas (Giones et al., 2013) and grow in an evolutionary way. The information from the cases presented here shows that one hybrid entrepreneur aims to become a full-time entrepreneur and use the time when he combines both wage job and self-employment to overcome the liability of newness and liability of smallness by taking time to build his customer base and a reputation. He also learned a lot on the way. A key finding is that, without the secure incomes from the waged jobs, it would be more difficult (or even impossible) for the new ventures to survive.

Not all entrepreneurs aim to become full-time entrepreneurs. Some enjoy a dual status of having a highpaid, secure, and prestigious job while also deriving some extra income from entrepreneurial activity that can further improve their lifestyle. It is neither good nor bad that some hybrid entrepreneurs do not have growth intentions and do not intend to switch from the hybrid entrepreneurship to full-time entrepreneurship. However, policy makers who are interested in growing the number of successful full-time entrepreneurs might wish to develop tailor-made programs to support hybrid entrepreneurs and encourage them to become fulltime entrepreneurs. Such programs might be even more successful in producing full-time entrepreneurship than entrepreneurship education programs that focus on fulltime entrepreneurship as the dominant model.

Hybrid entrepreneurship is a promising topic for policy development and academic research. In particular, several research avenues may be of interest to policy makers and scholars. First, research is needed regarding hybrid entrepreneurship among females. Previous research has not focused specifically on gender issues of hybrid entrepreneurship. This is an important avenue for hybrid entrepreneurship research given that female and male hybrid entrepreneurs have different motives to start a venture (Burke et al., 2008). Additionally, females still bear a greater responsibility for child care. Women have reported that child care has a negative influence on their entrepreneurial persistence (Burke et al., 2008). Better understanding of patterns that lie behind female and male hybrid entrepreneurship might give information for policy makers on how to increase the involvement of females in hybrid and full-time entrepreneurship.

Further research is required to understand the timing and decision-making processes of the switch to fulltime entrepreneurship or decisions to maintain a hybrid status. Such future research might apply different theories to investigate various aspects of hybrid entrepreneurship, such as entrepreneurial bricolage theory (Baker \& Nelson, 2005), effectuation theory (Sarasvathy, 2001), the theory of trying (Bagozzi et al., 1992), and gender theories. For example, using a lens of bricolage theory can help scholars to understand whether there is a difference between full-time self-employment and hybrid entrepreneurship in terms of using scarce resources. The effectuation perspective would allow investigation of the difference between full-time and hybrid entrepreneurs in utilization of causation and effectuation approaches.

Despite its limitations and exploratory nature, and the potential for future research in this area, the current study has implications for policy makers and education managers. The hybrid entrepreneurs studied here were not a focus of policy makers who develop and realize different support programmes for novice full-time entrepreneurs. The author's analyses of entrepreneurship 


\section{Hybrid Entrepreneurship: How and Why Entrepreneurs Combine Employment with Self-Employment} Marina Z. Solesvik

support programmes in Norway, such as those offered at the Skape.no Centre of Entrepreneurship in Rogaland (skape.no/om-oss/english-info), show that such programmes are aimed at developing entrepreneurial skills primarily among those with limited education and among those who have experienced difficulties finding jobs. I propose that policy makers should develop measures to support hybrid entrepreneurship programmes, especially among people with high levels of human capital but who are still under-represented among entrepreneurs, such as women and young people. Policy makers might also consider involving people from certain industries that are expected to decline in the future to acquire entrepreneurial skills in order to secure future smooth transitions from the declining industries into new spheres. In particular, this can be interesting approach for policy makers in oil-dependent economies (e.g., Norway, Russia, and Brazil). In Norway, offshore workers have generous free time schemes between the shifts in the sea. The recent downturn in the oil industry and related industries serving the oil rigs (e.g., offshore shipping) lead to job losses among highly educated engineers and other professionals. Those individuals who are hybrid entrepreneurs may prove to be more resilient and flexible during turbulent economic times should their "day jobs" disappear.

Educators from higher education institutions might consider adding hybrid entrepreneurship their enterprise education curriculums. Many academic programs focus on teaching people either to become entrepreneurs or to become professional managers. Insertion of issues related to honing of effectuation and bricolage skills as well as creativity might help future generations of entrepreneurs to combine "day jobs" with self-employment. Given recent and predicted future instability in the labour market, such approaches may become all the more important in the future. Different possibilities and opportunities related to the swift development of Internet technologies and virtual business platforms would only favour involvement of more and more people in hybrid entrepreneurship.

The study has also implications for owners and managers of firms where hybrid entrepreneurs are employed. It seems that nonstandard employment relations will play a more important role in the future. The employer perspective is scarcely researched in prior studies on hybrid entrepreneurship (Folta et al., 2010). Managers might consider developing a company policy related to employees doing business in addition to their main occupation, not as a way of discouraging the behaviour but as a way of encouraging openness and possibly as a means of retaining valued employees. The employer's perspective and degree of involvement - in terms of spin-offs or forms or corporate entrepreneurship, or even entrepreneurial behaviours within fulltime employment that may not be financially motivated - warrants study within the context of hybrid entrepreneurship as a stepping stone to full entrepreneurship.

\section{About the Author}

Marina Z. Solesvik is Professor and Chair of Maritime Innovation in the Nord University Business School, Norway. She also holds part-time positions in Norway as Professor at the University of Tromsø and Bergen University College. She is a board member at several Norwegian firms and organizations, including the National Riksteatret in Oslo. Marina holds a PhD in Management from the Nord University Business School and a PhD in Entrepreneurship from the Institute of Agrarian Economy in Kiev, Ukraine. Her research interests include regional innovation, open innovation, maritime business, entrepreneurial intentions, female entrepreneurship, strategic alliances, and Arctic research.

\section{References}

Bagozzi, R. P., Davis, F. D., \& Warshaw, P. R. 1992. Development and Test of a Theory of Technological Learning and Usage. Human Relations, 45(7): 659-686.

http://dx.doi.org/10.1177/001872679204500702

Baker, T., \& Nelson, R. E. 2005. Creating Something from Nothing: Resource Construction through Entrepreneurial Bricolage. Administrative Science Quarterly, 50(3): 329-366. http://dx.doi.org/10.2189/asqu.2005.50.3.329

Battilana, J., Lee, M., Walker, J., \& Dorsey, C. 2012. In Search of the Hybrid Ideal. Stanford Social Innovation Review, 10(3): 51-55.

Blanchflower, D. G., Oswald, A., \& Stutzer, A. 2001. Latent Entrepreneurship across Nations. European Economic Review, 45(4): 680-691.

http://dx.doi.org/10.1016/S0014-2921(01)00137-4

Boeije, H. 2009. Analysis in Qualitative Research. London: Sage Publications.

Bretz, M., Egeln, J., Gottschalk, S., Murmann, M., Niefert, M., Wagner, \& Simona, C. 2015. Mannheimer Gründungspanel 2014: Junge Unternehmen zurückhaltend bei Investionen und FuE. Zentrum für Europäische Wirtschaftsforschung, Mannheim.

Burke, A. E., FitzRoy, F. R., \& Nolan, M. A. 2008. What Makes a DieHard Entrepreneur? Beyond the 'Employee or Entrepreneur' Dichotomy. Small Business Economics, 31(2): 93-115. http://dx.doi.org/10.1007/s11187-007-9086-6 


\section{Hybrid Entrepreneurship: How and Why Entrepreneurs Combine Employment with Self-Employment}

\section{Marina Z. Solesvik}

Burmeister-Lamp, K., Lévesque, M., \& Schade, C. 2012. Are Entrepreneurs Influenced by Risk Attitude, Regulatory Focus or Both? An Experiment on Entrepreneurs' Time Allocation. Journal of Business Venturing, 27(4): 456-476.

http://dx.doi.org/10.1016/j.jbusvent.2011.12.001

Chesbrough, H. 2002. Graceful Exits and Missed Opportunities: Xerox's Management of Its Technology Spin-Off Organizations. Business History Review, 76(04): 803-837. http://doi.org/10.2307/4127710

Dees, J. G. 1998. The Meaning of Social Entrepreneurship. Stanford University. Draft Report for the Kauffman Center for Entrepreneurial Leadership. Kansas City, MO: Kauffman Center for Entrepreneurial Leadership.

http://www.redalmarza.cl/ing/pdf/TheMeaningofsocialEntreprene urship.pdf

European Commission. 2013. 37\% of Europeans would Like to Be Their Own Boss. European Commission, January 9, 2013. Accessed on November 21, 2016:

http://europa.eu/rapid/press-release_MEMO-13-7_en.htm

Folta, T. B., Delmar, F., \& Wennberg, K. 2010. Hybrid Entrepreneurship. Management Science, 56(2): 253-269. http://doi.org/10.1287/mnsc.1090.1094

Fowler, A. 2000. NGDOs as a Moment in History: Beyond Aid to Social Entrepreneurship or Civic Innovation? Third World Quarterly, 21(4): 637-654.

http://dx.doi.org/10.1080/713701063

Giones, F., Zhou, Z., Miralles, F., \& Katzy, B. 2013. From Ideas to Opportunities: Exploring the Construction of Technology-Based Entrepreneurial Opportunities. Technology Innovation Management Review, 3(6): 13-20.

http://timreview.ca/article/692

Kelley, D. J., Singer, S., \& Herrington, M. 2016. Global Entrepreneurship Monitor: 2015/2016 Global Report. London: Global Entrepreneurship Research Association.

http://www.gemconsortium.org/report/49480

Livingston, J. 2007. Founders at Work: Stories of Startups' Early Days. New York: Springer-Verlag.

Nicholls, A. (Ed.). 2008. Social Entrepreneurship: New Models of Sustainable Social Change. Oxford: Oxford University Press.

OECD. 2016. Self-Employment Rate (Indicator). Paris: Organisation for Economic Cooperation and Development (OECD). http://dx.doi.org/10.1787/fb58715e-en

Parsyak, V., \& Zhuravlyova, M. 2001. Small Business: Essence, State, and Means of Stability Support. Nikolaev, Ukraine: Ukrainian State Maritime Technical University.

Peng, M. W. 2001. How Entrepreneurs Create Wealth in Transition Economies. The Academy of Management Executive, 15(1): 95-108. http://doi.org/10.5465/AME.2001.4251397

Petrova, K. 2005. Part-Time Entrepreneurship and Wealth Effects: New Evidence from the Panel Study of Entrepreneurial Dynamics. Paper presented at the 50th ICSB Conference, Washington, DC, June, 15-18.

Petrova, K. 2012. Part-Time Entrepreneurship and Financial Constraints: Evidence from the Panel Study of Entrepreneurial Dynamics. Small Business Economics, 39(2): 473-493.

http://doi.org/10.1007/s11187-010-9310-7
Porket, J. L. 1989. Work, Employment and Unemployment in the Soviet Union. New York: Palgarve Macmillan.

Raffiee, J., \& Feng, J. 2014. Should I Quit My Day Job? A Hybrid Path to Entrepreneurship. Academy of Management Journal, 57(4): 936-963. http://doi.org/10.5465/amj.2012.0522

Sarasvathy, S. D. 2001. Causation and Effectuation: Toward a Theoretical Shift from Economic Inevitability to Entrepreneurial Contingency. Academy of Management Review, 26(2): 243-263. http://doi.org/10.5465/AMR.2001.4378020

Schmitt, J., \& Lane, N. 2009. An International Comparison of Small Business Employment. CEPR Reports and Issue Briefs, 27. Washington, DC: Center for Economic and Policy Research (CEPR).

Schulz, M., Urbig, D., \& Procher, V. 2016. Hybrid Entrepreneurship and Public Policy: The Case of Firm Entry Deregulation. Journal of Business Venturing, 31(3): 272-286.

http://dx.doi.org/10.1016/j.jbusvent.2016.01.002

Smallbone, D., \& Welter, F. 2001. The Distinctiveness of Entrepreneurship in Transition Economies. Small Business Economics, 16(4): 249-262.

http://doi.org/10.1023/A:1011159216578

Solesvik, M. 2016. Entrepreneurship, Human Capital, and Regional Development: Labour Networks, Knowledge Flows, and Industry Growth. International Journal of Entrepreneurial Behavior \& Research, 22(4): 584-586.

http://dx.doi.org/10.1108/IJEBR-12-2015-0301

Solesvik, M., Westhead, P., Matlay, H., \& Parsyak, V. 2013. Entrepreneurial Assets and Mindsets: Benefit from University Entrepreneurship Education Investment. Education + Training, 55(8/9): 748-762.

http://dx.doi.org/10.1108/ET-06-2013-0075

Stuart, T. E., \& Sorenson, O. 2003. Liquidity Events and the Geographic Distribution of Entrepreneurial Activity. Administrative Science Quarterly, 48(2): 175-201. http://doi.org/10.2307/3556656

Thorgren, S., Nordström, C., \& Wincent, J. 2014. Hybrid Entrepreneurship: The Importance of Passion. Baltic Journal of Management, 9(3): 314-329. http://dx.doi.org/10.1108/BJM-11-2013-0175

Thorgren, S., Sirén, C., Nordström, C., \& Wincent, J. 2016. Hybrid Entrepreneurs' Second-Step Choice: The Nonlinear Relationship between Age and Intention to Enter Full-Time Entrepreneurship. Journal of Business Venturing Insights, 5(1): 14-18. http://dx.doi.org/10.1016/j.jbvi.2015.12.001

Westhead, P., \& Solesvik, M. 2016. Entrepreneurship Education and Entrepreneurial Intention: Do Female Students Benefit? International Small Business Journal, 34(8): 979-1003. http://doi.org/10.1177/0266242615612534

World Atlas. 2016. 15 Countries with the Lowest Rate of SelfEmployment. World Atlas, August 8, 2016. Accessed March 1, 2017: http://www.worldatlas.com/articles/15-countries-with-the-lowestrates-of-self-employment.html

Citation: Solesvik, M. Z. 2017. Hybrid Entrepreneurship: How and Why Entrepreneurs Combine Employment with Self-Employment. Technology Innovation Management Review, 7(3) 33-41. http://timreview.ca/article/1063

Keywords: hybrid entrepreneurship, hybrid entrepreneurs, self-employment, definitions, risk taking 